\title{
Integration of the Bride as a Requirement for a Valid Customary Marriage: Mkabe v Minister of Home Affairs [2016] ZAGPPHC 460
}

\section{P Bakker*}

\section{P.E.R}

Pioneer in peer-reviewed, open access online law publications

Author

Pieter Bakker

Affiliation

University of the Witwatersrand South Africa

Email bakkep@unisa.ac.za

Date of submission

27 February 2017

Date published

13 March 2018

Editor Prof W Erlank

How to cite this article

Bakker $\mathrm{P}$ "Integration of the Bride as a Requirement for a Valid Customary Marriage: Mkabe v Minister of Home Affairs [2016] ZAGPPHC 460" PER / PELJ 2018(21) - DOI

http://dx.doi.org/10.17159/17273781/2018/v21i0a1737

Copyright

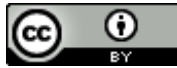

DOI

http://dx.doi.org/10.17159/17273781/2018/v21i0a1737

\begin{abstract}
Since the Recognition of Customary Marriages Act 120 of 1996 was promulgated in 15 November 2000 the courts are faced with the daunting task to determine whether a customary marriage is valid under the Act. The courts find it troublesome to determine exactly what the essential requirements under the living customary law are. One of the issues the courts have to deal with is the question whether the incorporation of a bride into her husband's family is an essential requirement for a valid customary marriage or can the families waive the requirement or condone non-compliance? The court in Mkabe $v$ Minister of Home Affairs [2016] ZAGPPHC 460 found that the requirement can be waived or condoned. This case note criticises the Mkabe decision and illustrates why the incorporation of the bride is indeed an essential requirement for a valid customary marriage.
\end{abstract}

\section{Keywords}

Customary Law, Customary Marriage, Recognition of Customary Marriages Act, Mkabe v Minister of Home Affairs. 


\title{
1 Introduction
}

Section 3(1)(b) of the Recognition of Customary Marriages Act 120 of $1998^{1}$ determines the validity of customary marriages concluded after the Act. The first two requirements are clear: the parties must be above the age of 18 or have the required consent and the parties must consent to be married to each other under customary law. ${ }^{2}$ The courts are faced, however, with the daunting task of determining whether a customary marriage is valid under section 3(1)(b) of the Act. Section 3(1)(b) requires that for a customary marriage to be valid it must be "negotiated and entered into or celebrated in accordance with customary law".

According to the courts, section 3(1)(b) elevates the customary law requirements for a valid customary marriage to legal requirements for a valid customary marriage under the Customary Marriages Act. ${ }^{3}$ This approach was confirmed by the Constitutional Court in $M M v M N$ :

\begin{abstract}
Section 3(1)(b) goes on to stipulate that 'the marriage must be negotiated and entered into or celebrated in accordance with customary law'. Customary law may thus impose validity requirements in addition to those set out in ss (1)(a). In order to determine such requirements a court would have to have regard to the customary practices of the relevant community. ${ }^{4}$
\end{abstract}

The courts regard three requirements or stages in the marriage process as essential requirements for a valid customary marriage under section $3(1)(b)$ : family participation, a lobolo agreement, and integration of the bride into the husband's family. ${ }^{5}$ In this regard Matlapeng AJ comments in Matsoatsoa $v$ Roro:

Pieter Bakker. BLC, LLB, LLD (UP). Professor, Department of Private Law, UNISA. E-mail: bakkep@unisa.ac.za.

\# The publication was made possible through the receipt of funding from the University of South Africa College Research and Innovation Committee. Any opinions expressed in the publication, however, are solely those of the author.

1 Recognition of Customary Marriages Act 120 of 1998 (hereafter the Customary Marriages Act).

2 Section 3(1)(a) of the Customary Marriages Act.

$3 \quad$ Mrapukana $v$ Master of the High Court 2008 ZAWCHC 113 (21 November 2008); Maloba v Dube 2008 ZAGPHC 434 (23 June 2008); Matsoatsoa v Roro 20112 All SA 324 (GSJ); Moropane v Southon 2014 JOL 32177 (SCA); Bennett Customary Law 199.

$4 \quad$ MM v MN 20134 SA 415 (CC) para [29].

5 These requirements are present in the traditions of all South African tribes. Sila $v$ Masuku 1937 NAC 121 (N\&T); Fanti v Boto 20085 SA 405 (C) para [19]; Matsoatsoa $v$ Roro 20112 All SA 324 (GSJ) para [19]; Ntoagae v Makabanyane 2015 ZANWHC 78 (11 December 2015) para [12]; Rautenbach and Bekker Legal Pluralism 101-102; Himonga and Moore Reform of Customary Marriage 73, 82-83, 88-89. 
[A] customary marriage in true African tradition is not an event but a process that comprises a chain of events. Furthermore, it is not about the bride and the groom. It involves the two families. The basic formalities which lead to a customary marriage are: emissaries are sent by the man's family to the woman's family to indicate interest in the possible marriage (this of course presupposes that the two parties man and woman have agreed to marry each other); a meeting of the parties' relatives will be convened where lobolo is negotiated and the negotiated lobolo or part thereof is handed over to the woman's family and the two families will then agree on the formalities and date on which the woman will then be handed over to the man's family which handing over may include but not necessarily be accompanied by celebration (wedding). ${ }^{6}$

Of the essential stages the integration of the bride into the husband's family is regarded as the final stage; without it no valid customary marriage can be concluded. In Moropane $v$ Southon the Supreme Court of Appeal found:

... the handing over of the makoti to her in-laws is the most crucial part of a customary marriage. This is so as it is through this symbolic customary practice that the makoti is finally welcomed and integrated into the groom's family which henceforth becomes her new family. ${ }^{7}$

Although the Supreme Court of Appeal confirmed that the integration of the bride is the final stage in concluding a customary marriage, courts often grapple with the question whether a bride was indeed incorporated into the husband's family. ${ }^{8}$ A recent example is the decision of the North Gauteng High Court, Pretoria in Mkabe $v$ The Minister of Home Affairs (hereafter Mkabe). Even though the Supreme Court of Appeal confirmed that the integration of the bride is the final stage in the process of concluding a customary marriage, Mkabe finds that the parties can do away with the integration of the bride by agreement. ${ }^{9}$ Mkabe is analysed to determine whether the parties can indeed waive or condone the essential requirements of a customary marriage through agreement.

Matsoatsoa v Roro 20112 All SA 324 (GSJ) para [17].

Moropane $v$ Southon 2014 JOL 32177 (SCA) para [40].

There is currently uncertainty in the courts whether families can agree not to integrate the bride. There are opposing decisions in the High Courts. In Msutu $v$ Road Accident Fund 2011 ZAGPPHC 232 (10 July 2011); C v P 2017 ZAFSHC 57 (6 April 2017) and Mkabe $v$ Minister of Home Affairs 2016 ZAGPPHC 460 (9 June 2016) (hereafter Mkabe) the courts found that the families can agree to waive integration of the bride into the husband's family; and in Fanti v Boto 20085 SA 405 (C); Mrapukana v Master of the High Court 2008 ZAWCHC 113 (21 November 2008); Maluleke v Minister of Home Affairs 2008 ZAGPHC 129 (9 April 2008); Ndlovu v Mokoena 20095 SA 400 (GNP); Matsoatsoa v Roro 20112 All SA 324 (GSJ); Mxiki v Mbata: In re: Mbata v Department of Home Affairs 2014 ZAGPPHC 825 (23 October 2014) integration was required. 


\section{Facts}

A brief discussion of the facts is required to provide a background to the court's decision. The plaintiff (a Swazi) seeks a declaratory order that a valid customary marriage existed between him and the deceased (a Tsonga). The matter is opposed by the daughter and the elder brother of the deceased. The parties are in agreement that lobolo was negotiated and partially delivered. ${ }^{10}$

The plaintiff indicates that he and the deceased did not plan a marriage celebration or handing over ceremony. ${ }^{11} \mathrm{He}$ testified that they considered themselves married without the deceased being handed over to his family. ${ }^{12}$ No one from the deceased's family requested him to perform any further custom to finalise his marriage, and he continued to live with the deceased as husband and wife. ${ }^{13}$

The plaintiff testified that he does not have any knowledge of the Tsonga traditions but according to Swazi traditions one only needs to pay part of the lobolo for a valid customary marriage and no handing over ceremony is required. ${ }^{14}$

As to the Tsonga customs, the son of the deceased testified that the payment of lobolo is not sufficient to conclude a valid customary marriage; it merely creates a bond between the two families. ${ }^{15}$ The second defendant, the elder brother of the deceased and the family elder, testified that the parties agreed that lobolo will be delivered in full before the deceased would be handed over to the plaintiff's family, and this never happened. ${ }^{16}$

\footnotetext{
$10 \quad$ Mkabe para [3].

11 The process is also known as the integration of the bride into the husband's family. The latter formulation is preferred as the process of integration involves more than merely delivering the bride at her husband's family home. The court refers to "handing over" and the terms are therefore used interchangeably in this discussion. Mkabe para [6].

Mkabe para [8].

Mkabe paras [12] and [24].

Mkabe para [15].

Mkabe para [16].
} 


\section{Judgement}

The court regards the plaintiff as a reliable witness and places emphasis on his testimony as opposed to that of the second defendant, the elder of the deceased's family. ${ }^{17}$

The case for the defendant was that the lobolo was not paid in full and that the bride was not handed over and therefore no valid customary marriage existed between the plaintiff and the defendant. The court finds full payment of lobolo is not a requirement for a valid customary marriage. ${ }^{18}$

The families agreed that the plaintiff and deceased can marry, lobolo was agreed upon and partially paid. All the requirements for a valid customary marriage were therefore met except for the integration of the deceased into the plaintiff's family.

Twala AJ quotes from Mabuza v Mbatha, where the court found that "(t)here is no reason... why failure to observe some of the rituals or ceremonies cannot be waived or condoned by the parties in terms of an agreement between them". ${ }^{19}$ Twala AJ then finds that the integration of the deceased "cannot be over emphasised [more] than the other requirements to invalidate the conclusion of a customary marriage".20 Naturally all the essential requirements must be present for a valid customary marriage to exist - one requirement does not carry more weight than another. ${ }^{21}$

The judge finds that the deceased and the plaintiff had been living together at the time of the lobolo negotiations and lobolo was delivered partially. Twala AJ consequently finds that

... with the testimony of the plaintiff that he was not aware nor was he alerted that there was [an]other ritual and/or custom to be observed and the undisputed fact that she returned to her husband on her own... after ilobolo was paid and the other rituals performed, the handover of the bride to the family of the plaintiff was condoned and/or waived by the parties. ${ }^{22}$

The court infers the waiver or condonation of the integration of the bride on two facts. First, the plaintiff was not aware of or alerted to any additional

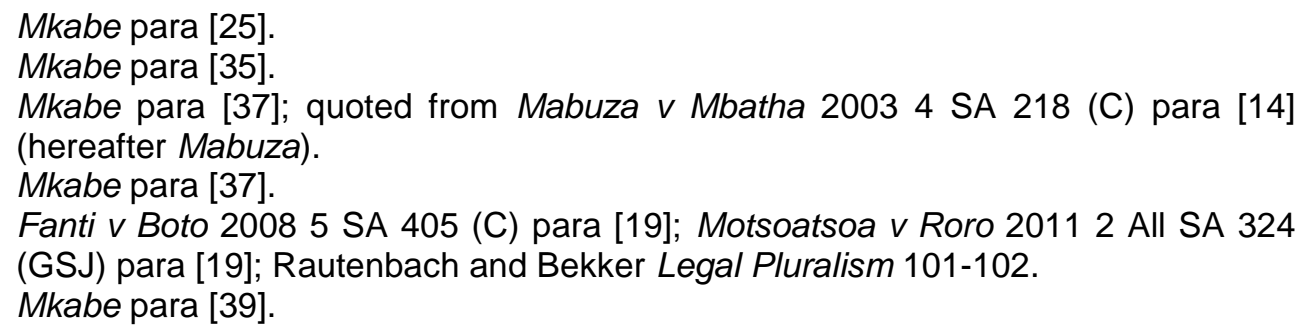


requirement by the deceased's family, and secondly, the deceased returned to the plaintiff after the payment of lobolo, whereafter they continued to live together as husband and wife. ${ }^{23}$ The court therefore concludes that a valid customary marriage existed between the plaintiff and the deceased as lobolo was partially paid and the parties waived the requirement of the integration of the bride. ${ }^{24}$

\section{Comments on the judgement}

\subsection{Waiver or condonation of integration}

The court was bound by the Supreme Court decision in Southon $v$ Moropane, which regards integration as an essential requirement for a valid customary marriage. No reference was made to this judgement and it can be assumed that the court was not aware of the decision. Accepting that integration is an essential requirement for a valid customary marriage the logical question is whether Twala AJ is correct in finding that the families can waive or condone an essential requirement for a valid customary marriage.

Twala AJ correctly states that one requirement cannot be privileged above another. ${ }^{25}$ If the parties are able to waive or condone the integration of the bride, which is an essential requirement for a valid customary marriage, then this would imply that the parties will be able to waive or condone any essential requirement applicable under section 3(1)(b). The parties would, for example, be able to agree that the lobolo negotiations will be waived. The author cannot foresee that any indigenous community would regard anyone as married under customary law if they did not conduct lobolo negotiations. In a current study conducted by Himonga and Moore the "[m]arried participants - both men and women - stressed the importance of lobolo... They were clear that partners living together without lobolo were merely cohabiting". ${ }^{26}$

Just as lobolo negotiations are an integral part of the customary marriage process, so is the integration of the bride. In the same study quoted above, Himonga and Moore conclude:

Our study confirmed the prominence of the practice of integration of the wife in the process of negotiation of marriages in practice ... This practice is

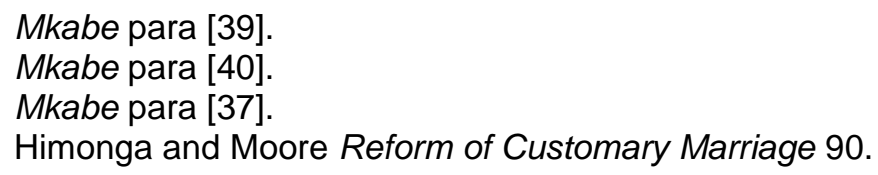


characterised by the ritual of animal slaughter ... the animal slaughter ritual was identified ... as having symbolic meaning for the conclusion of the marriage. ${ }^{27}$

In Mkabe, Twala AJ did not comprehend the cultural relevance of the integration of the bride into the husband's family. The integrating of the bride plays a crucial cultural and religious part in the customary marriage process. ${ }^{28}$ Integration symbolises and broadcasts the acceptance of the makoti (bride) by the husband's family and confirms her willingness to be accepted into his family. ${ }^{29}$ Integration possesses a pivotal religious component consisting of the introduction of the bride to their ancestors as a new member of the husband's family. To obtain the ancestors' blessing and acceptance of the new member of their family the ancestors' support is canvassed by the husband's family through certain rituals. ${ }^{30}$

The integration of the bride is not the only requirement but is inevitably the final step parties need to take before they are regarded as married in terms of customary law. ${ }^{31}$ Ultimately this is the view of the Supreme Court of Appeal and lower courts are bound by this decision. ${ }^{32}$

Why did Twala AJ then come to the conclusion that an essential requirement can be waived? His decision is based on Mabuza or rather on an erroneous reading of the case.

\subsection{Mabuza v Mbatha}

The crux of the Mkabe decision is based on the decision of the Cape provincial division of the high court (now Western Cape division of the high court) by Hlope JP in Mabuza. The case is erroneously cited as authority that the integration of the bride can be waived by agreement between the families of the bride and groom. ${ }^{33}$

Twala AJ quoted from the headnote of Mabuza:

African customary law has evolved and was always flexible in application. There is thus no doubt that the siSwati custom of ukumekeza (i.e. the formal

$27 \quad$ Himonga and Moore Reform of Customary Marriage 92-93.

$28 \quad$ Marwick The Swazi 103; Bennett Sourcebook 192; Van Schalkwyk Indigenous Law of Contract 186-187; Himonga and Moore Reform of Customary Marriage 92-93.

29 Bennett Customary Law 217.

$30 \quad$ Sila v Masuku 1937 NAC 121 (N\&T) 123; Bennett Customary Law 213.

$31 \quad$ Matsoatsoa v Roro 20112 All SA 324 (GSJ) para [18]; Bennett Sourcebook 192; Bekker 2004 THRHR 150; Himonga and Moore Reform of Customary Marriage 93.

32 Moropane $v$ Southon 2014 JOL 32177 (SCA) para [40].

33 Mkabe para [34]; Mwambe and Kruuse 2013 Acta Juridica 309-310; Nkosi 2015 De Rebus 67. 
integration of the bride into the family of the bridegroom, the custom being one of the three requirements for a valid marriage according in siSwati customary law), like so many other customs, has somehow evolved so much that it is probably practised differently from what it was centuries ago. It is inconceivable that ukumekeza has not evolved and that it cannot be waived by agreement between the parties and/or their families in appropriate cases. ${ }^{34}$

The headnote gives the impression that ukumekeza is the integration of the bride and due to social change can be waived by agreement between the parties. However, a careful reading of Mabuza shows that the headnote combines three different (mostly unrelated) paragraphs in the decision into one paragraph. The first sentence of the headnote, namely that "African customary law has evolved and was always flexible in application", comes from a quote from Bennett $A$ Sourcebook in paragraph [26] of Mabuza:

[C] ]ustomary law was always flexible and pragmatic. Strict adherence to ritual formulae was never absolutely essential in close-knit, rural communities, where certainty was neither a necessity nor a value. So, for instance, the ceremony to celebrate a man's second marriage would normally be simplified; similarly, the wedding might be abbreviated by reason of poverty or the need to expedite matters. ${ }^{35}$

Bennett here discusses the fact that marriage ceremonies are abbreviated when required. The passage does not relate to the essential requirements of a valid customary marriage but merely to the rituals practised during the different stages of the marriage process. Bennett does continue by noting that the courts did not require the physical handing over of the bride prior to the Customary Marriages Act. The courts instead placed more emphasis on the intention of the parties - which the courts inferred from the cohabitation of the parties after payment of lobolo. ${ }^{36}$ In a subsequent publication Bennett ${ }^{37}$ again refers to the above but indicates that the South African Law Reform Commission (hereafter SALRC) proposed that the only consideration in determining whether a customary marriage is valid should be the intention of the parties to conclude a customary marriage. ${ }^{38}$ This approach does not regard any traditional customary requirement as essential and the parties are free to observe any of the customs they prefer. ${ }^{39}$ Unfortunately this is not how the courts interpreted section 3(1)(b). ${ }^{40}$ In $M M v M N$ the Constitutional Court declared that section 3(1)(b)

$34 \quad$ Mkabe para 34.

35 Bennet Sourcebook 194.

36 Bennet Sourcebook 195.

37 Customary Law 215-217.

38 SALRC Harmonisation para 4.4.9-10.

39 SALRC Project 90.

40 See Bakker 2013 Obiter 586-588 for a discussion of the SALRC's approach. Although the presumption that only the intention of the parties should determine the validity of a customary marriage is preferable to the insistence on adherence to a set 
integrates the traditional requirements for a customary marriage as requirements for a valid customary marriage under section $3(1)(b) .{ }^{41}$ This decision inevitably led to the decision of the Supreme Court of Appeal in Moropane $v$ Southon, which declared that the integration of the bride is an essential requirement. ${ }^{42}$ The passage quoted by the court from Bennett in Mkabe does not relate to the essential requirements, but only to the rituals or ceremonies associated with the requirements. Rituals or ceremonies can be abbreviated if required.

The second part of the headnote:

[t]here is thus no doubt that the siSwati custom of ukumekeza (i.e. the formal integration of the bride into the family of the bridegroom, the custom being one of the three requirements for a valid marriage according in siSwati customary law) ...

comes from a statement made by the plaintiff under cross-examination:

... there were three requirements for a valid African marriage according to siSwati customary law. The first was the payment of ilobolo, the second was ukumekeza (which means the formal integration of the bride into the bridegroom's family) and the third one was the formal handing over of the bride to the bridegroom's family. 43

The three requirements referred to are not the three essential requirements for a customary marriage that come to mind when reading the headnote. The passage in fact discusses two of the three essential requirements - the lobolo payment, which should be the lobolo agreement, as payment is not required; 44 and the integration of the bride. The passage differentiates between integration (ukumekeza) and handing over. The differentiation is artificial and was devised by the defendant's expert to place more emphasis on ukumekeza. ${ }^{45}$ Ukumekeza is one of the rituals performed during the integration (handing over) of the bride, together with other rituals such as libovu (the smearing of red ochre), and cannot be regarded as an essential requirement. ${ }^{46}$ The plaintiff was integrated, and only ukumekeza was not performed. In this regard Hlophe JP states: "In casu nothing else was

of essential requirements, the current law requires such adherence. This position can be amended only by the legislature.

$41 \quad$ MM v MN 20134 SA 415 (CC) para [39].

$42 \quad$ Moropane $v$ Southon 2014 JOL 32177 (SCA) paras [37] and [40].

$43 \quad$ Mkabe para [9].

$44 \quad$ Motsoatsoa v Roro 20112 All SA 324 (GSJ) para [17]; Southon v Moropane 2012 ZAGPJHC 146 (18 July 2012) para [82].

$45 \quad$ Mkabe para [26]; see the quote below.

46 Under the Swazi custom the exact ritual that signifies the conclusion of the marriage during the integration ceremony is the libovu - the smearing of red ochre; see Van Schalkwyk Indigenous Law of Contract 186; Nkosi 2004 Speculum Juris 327. 
outstanding [except ukumekeza]. llobolo had been paid and there was the formal handing over of the bride to the bridegroom's family". ${ }^{47}$ Ukumekeza is merely part of the marriage celebrations, and can be abbreviated, as Bennett acknowledges in the passage quoted above. The families in Mabuza did not agree to waive the integration of the bride. They waived only ukumekeza.

This brings us to the third part of the headnote:

[Ukumekeza] like so many other customs, has somehow evolved so much that it is probably practised differently from what it was centuries ago. It is inconceivable that ukumekeza has not evolved and that it cannot be waived by agreement between the parties and/or their families in appropriate cases.

The above comes from the following paragraph in Mabuza:48

\begin{abstract}
In my judgement, there is no doubt that ukumekeza, like so many other customs, has somehow evolved so much that it is probably practised differently than it was centuries ago. I got a firm impression that Mr Shongwe [expert for the defendant] was not being truthful to the Court insofar as he attempted to elevate ukumekeza into something so indispensable that without it there could be no valid siSwati marriage. It is my view that his evidence in that regard cannot be safely relied upon. As Professor De Villiers testified, it is inconceivable that ukumekeza has not evolved and that it cannot be waived by agreement between the parties and/or their families in appropriate cases.
\end{abstract}

The conclusion reached here is correct. One of the rituals, such as ukumekeza, can be waived by agreement between the families. But the passage does not claim that the essential requirement of the integration of the bride can be waived. It only notes that ukumekeza is not an essential requirement as alleged by the defendant's expert.

The reading of the headnote creates the unfortunate impression that the court found that the integration of the bride (one of the essential requirements) can be waived by agreement between the families. This is the impression that Twala AJ had of the Mabuza-case when he handed down his judgement.

It is not the essential requirements that can be waived but rather the rituals associated with the essential requirements. If the rituals and ceremonies associated with the essential requirements of a customary marriage could be abbreviated or waived by agreement, the next logical question to ask

\footnotetext{
47 Mkabe para [14]. The court regards "formal handing over" as the physical act of delivering the bride to the husband's family, which is another ritual in the process of the integration of the bride. The parties had therefore complied with the requirement of integration or handing over. Mkabe para [26].
} 
would be whether the parties could waive all the required rituals or ceremonies of the integration of the bride and still conclude a valid customary marriage.

\subsection{A matter of evidence}

The validity of a customary marriage is in dispute only in the event of a divorce or the death of one of the spouses. The spouse who alleges that he or she is married in terms of customary law has to prove that the parties complied with the essential requirements for a valid customary marriage, including the integration of the bride. ${ }^{49}$ The intention to integrate is a subjective aspect that needs to be proved by objective facts ex post factu. . $^{50}$ Some form of ritual or ceremony is required to prove the integration of the bride into the groom's family. ${ }^{51}$ The parties can therefore not waive all the rituals associated with the integration of the bride; there needs to be some form of ritualistic integration that can be used to prove a valid customary marriage. Due to the adaptable nature of customary law this can take on any form the parties regard as sufficient. In other words, the parties do not need to follow all the requirements for integration as prescribed in their tribal tradition, but what they do should be sufficient to prove their intention to integrate the bride into the husband's family.

Although integration is regarded as an essential requirement for a customary marriage, a party can argue that the customs have changed to such an extent that the integration of the bride is not a requirement for a valid customary marriage. However, the court can not merely take judicial notice of this aspect, and it will have to be proved. The reason for this is that customary law is both a matter of law and a matter of fact. ${ }^{52}$ The court can take judicial notice of the official customary law, which includes any decision made by a court on an aspect of living customary law which by implication then becomes official law. ${ }^{53} \mathrm{~A}$ deviation in living customary law from the official customary law must be proved by the party alleging this. ${ }^{54}$

$49 \quad$ MG v BM 20122 SA 253 (GSJ) para [10]; Ntoagae $v$ Makabanyane 2015 ZANWHC 78 (11 December 2015) para [14]. Moropane $v$ Southon $2014 \mathrm{JOL} 32177$ (SCA) para [51]. Moropane $v$ Southon 2014 JOL 32177 (SCA) paras [52]-[55].

Bennett Customary Law 48; Rautenbach 2017 PELJ 18-19.

Bennett Customary Law 48-49; Bakker 2016 THRHR 359.

Shilubana v Nwamitwa 20089 BCLR 914 (CC) paras 44-49; Bennett Customary Law 48-49; Rautenbach 2017 PELJ 19. 
Whether a valid customary marriage was concluded is therefore a matter of evidence and the party alleging a change in custom or deviation from official customary law will have to prove the change or deviation.

\section{Conclusion}

After the decision in Moropane $v$ Southon the integration of the bride is a requirement for a valid customary marriage in the official customary law. A deviation can be allowed only if it can be proved that the living customary law of a certain tribe has evolved to such an extent that integration of the bride can no longer be regarded as an essential requirement for a valid customary marriage.

The view of Twala AJ in Mkabe that the integration of the bride (an essential requirement for a valid customary marriage) can be waived or condoned by agreement between the parties cannot be followed. The decision is based on an error in law due to an incorrect reading of Mabuza. The essential requirements of a customary marriage cannot be waived or condoned, but the accompanying rituals or ceremonies may be waived or abbreviated by the parties. Parties concluding a customary marriage must always keep in mind that the rituals are performed to provide proof that a valid customary marriage did take place, should such proof be required in the event of divorce or death. For this reason, it is not possible to waive all the rituals relevant to an essential requirement of a customary marriage.

The SALRC intended that section 3(1)(b) should not incorporate a list of essential requirements for a valid customary marriage but rather provide for factors that can contribute towards the proof of the intention of the parties to conclude a customary marriage. The only requirement for a valid customary marriage according to the SALRC, apart from the age and consent requirements, is the intention to conclude a marriage in accordance with customary law. Such an approach might be preferential, but unfortunately the courts have not taken heed of this approach and have decided that the essential requirement in customary law should be incorporated into the Customary Marriages Act. The position can be amended only by the legislature. 


\section{Bibliography}

\section{Literature}

Bakker 2013 Obiter

Bakker P "Bewys van ' $n$ Gebruiklike Huwelik Kragtens Artikel 3(1)(b) van die Wet op Erkenning van Gebruiklike Huwelike 120 van 1998: Southon v Moropane [2012] ZAGPJHC 146" 2013 Obiter 579-589

Bakker 2016 THRHR

Bakker $\mathrm{P}$ "The Validity of a Customary Marriage under the Recognition of Customary Marriages Act 120 of 1998 with Reference to Sections 3(1)(b) and 7(6) - Part 2" 2016 THRHR 357-368

Bekker 2004 THRHR

Bekker JC "Requirements for the Validity of a Customary Marriage: Mabuza v Mbatha 20034 SA 218 (C)" 2004 THRHR 146-150

Bennett Sourcebook

Bennett TW A Sourcebook of African Customary Law (Juta Cape Town 1991)

Bennett Customary Law

Bennett TW Customary Law in South Africa (Juta Cape Town 2004)

Himonga and Moore Reform of Customary Marriage

Himonga C and Moore E Reform of Customary Marriage, Divorce and Succession in South Africa (Juta Cape Town 2015)

Marwick The Swazi

Marwick BA The Swazi: An Ethnographic Account of the Natives of the Swaziland Protectorate (Cambridge University Press London 1940)

Mwambe and Kruuse 2013 Acta Juridica

Mwambe $L$ and Kruuse $H$ "Form over Function? The Practical Application of the Recognition of Customary Marriages Act 1998 in South Africa" 2013 Acta Juridica 292-317

Nkosi 2004 Speculum Juris

Nkosi G "The Extent of Recognition of Customs in Indigenous Law of Marriage: Mabuza v Mbatha [2003] 1 All SA 706 (C)" 2004 Speculum Juris 325-329 
Nkosi 2015 De Rebus

Nkosi S "Customary Marriage as dealt with in Mxiki v Mbata in re: Mbata $v$ Department of Home Affairs and Others (GP) (Unreported Case No A844/2012, 23-10-2014) (Matojane J)" 2015 (Jan/Feb) De Rebus 67

Rautenbach 2017 PELJ

Rautenbach C "Oral Law in Litigation in South Africa: An Evidential Nightmare?" 2017 PELJ 1-25

Rautenbach and Bekker Legal Pluralism

Rautenbach C and Bekker JC (eds) Introduction to Legal Pluralism (LexisNexis Durban 2014)

SALRC Project 90

South African Law Reform Commission Project 90: The Harmonisation of the Common Law and the Indigenous Law: Report on Customary Marriages (SALRC Pretoria 1998)

Van Schalkwyk Indigenous Law of Contract

Van Schalkwyk A The Indigenous Law of Contract with Particular Reference to the Swazi in the Kingdom of Swaziland (LLD-thesis UNISA 2006)

\section{Case law}

C v P 2017 ZAFSHC 57 (6 April 2017)

Fanti v Boto 20085 SA 405 (C)

Mabuza v Mbatha 20034 SA 218 (C)

Maloba v Dube 2008 ZAGPHC 434 (23 June 2008)

Maluleke v Minister of Home Affairs 2008 ZAGPHC 129 (9 April 2008)

Matsoatsoa v Roro 20112 All SA 324 (GSJ)

MG v BM 20122 SA 253 (GSJ)

Mkabe $v$ Minister of Home Affairs 2016 ZAGPPHC 460 (9 June 2016)

$M M v M N 20134$ SA 415 (CC)

Moropane v Southon 2014 JOL 32177 (SCA) 
Mrapukana v Master of the High Court 2008 ZAWCHC 113 (21 November 2008)

Msutu v Road Accident Fund 2011 ZAGPPHC 232 (10 July 2011)

Mxiki v Mbata: In re: Mbata v Department of Home Affairs 2014 ZAGPPHC 825 (23 October 2014)

Ndlovu v Mokoena 20095 SA 400 (GNP)

Ntoagae v Makabanyane 2015 ZANWHC 78 (11 December 2015)

Shilubana v Nwamitwa 20089 BCLR 914 (CC)

Sila v Masuku 1937 NAC 121 (N\&T)

Southon v Moropane 2012 ZAGPJHC 146 (18 July 2012)

\section{Legislation}

Recognition of Customary Marriages Act 120 of 1998

\section{List of Abbreviations}

PELJ

SALRC

THRHR
Potchefstroom Electronic Law Journal South African Law Reform Commission Tydskrif vir Hedendaags RomeinsHollandse Reg 